\title{
Tržište i grad: \\ Simbioza poduzeća i općine u Jugoslaviji na primjeru Građevnog kombinata Međimurje - Čakovec (1963.-1981.)
}

\author{
SAŠA VEJZAGIĆ \\ European University Institute, Firenca
}

\begin{abstract}
Sažetak
Članak prati ekspanziju Građevnog kombinata Međimurje iz Čakovca od njegova nastanka u 1960-ima do vrhunca svog poslovnog razvoja na samom kraju 1970-ih. S jedne strane članak predstavlja zanimljivu povijest tehnokracije, poduzetništva i poslovnog razvoja u vrijeme deregulirane planske ekonomije. $\mathrm{S}$ druge priča o modernizacijskom iskustvu jugoslavenske agrarne periferije $\mathrm{i}$ provincijalnog grada na samim marginama političkog interesa Beograda i Zagreba. Ovo istraživanje, između ostalog, ističe najvažnije karakteristike stvaranja velikih poslovnih sustava u samoupravljanju, a istovremeno proučava odnose i interakciju između poslovne i političke domene na lokalnoj razini. Također posredno preispituje uspjeh tržišne reforme u Jugoslaviji i istražuje odnose između poduzeća i Partije.
\end{abstract}

Ključne riječi: GK Međimurje, Čakovec, Jugoslavija, poslovna povijest, samoupravljanje

\section{Uvod}

Od svojeg dolaska na vlast 1945. jugoslavenski komunisti su postupno formirali novi društveno-ekonomski sustav, svjesno ili nesvjesno primjenjujući, kako je zove Susan Woodward, "strategiju u pokretu" (Woodward, 1995: 31). ${ }^{1}$ Novi društveni poredak, njegovi vrijednosni okviri i službena ideologija dinamično su se oblikovali pod raznim unutarnjim i vanjskim političkim, ekonomskim i socijalnim utjecajima, balansirajući između marksističkog ideala i zatečenih okolnosti. Jedna od takvih prilagodbi u poslijeratnoj Jugoslaviji bila je zadržavanje zakona vrijednosti

${ }^{1}$ Ovaj rad financirala je Hrvatska zaklada za znanost projektom HRZZIP-01-2018-5394. 
na kojem je do svoje smrti 1953. inzistirao najistaknutiji partijski ekonomist Boris Kidrič, dok su ga sve ostale planske ekonomije uglavnom odbacivale kao nepotrebno nasljeđe kapitalizma (Kidrič, 1949). Zadržavanje zakona vrijednosti bilo je suprotno ustaljenom uvjerenju da je "jugoslavenski socijalizam" bio samo kopija sovjetskog modela te da je tek kasnije kroz razna prilagođavanja modificirao svoju arhitekturu, ali načelno nikada nije napustio boljševički uzor društvenog razvoja (Bilandžić, 1999; Lampe, 1996; Radelić, 2006). Krajem 1950-ih, međutim, daljnja integracija tržišnih principa intenzivirala se na krilima sve prisutnije krilatice "svakome prema zaslugama", koja je u političkom i javnom prostoru trebala dati ideološki legitimitet novom valu nadolazećih modernizacijskih reformi (Rusinow, 1977: 150; Program SKJ, 1958). Drugim riječima, spomenuti postulat jugoslavenskim revolucionarima u konačnici nije poslužio kao alat u borbi za savladavanje kontradikcija "kapital odnosa", već za njihovo opravdanje.

No Tito, Edvard Kardelj, Boris Kidrič te tada još uvijek partijski prihvatljiv Milovan Đilas ipak su garanciju za socijalistički karakter poretka vidjeli u samoupravnom projektu. U praksi je, međutim, ideja šire društvene kontrole nad sredstvima za proizvodnju, ali i svim ostalim segmentima države bila ograničena, a nakon što se Jugoslavija jače izložila svjetskom robnom i financijskom tržištu, projekt samoupravljanja bio je bespovratno kompromitiran. Također, povijest i sudbina "jugoslavenskog puta u socijalizam" u najmanju su ruku dovele u pitanje karakteriziranje jugoslavenske povijesti druge polovice 20. stoljeća kao socijalističke. U tom smislu ovu premisu ne bih koristio kao neku vrstu polazišne osnove proučavanja ekonomsko-poslovnih prilika u zreloj dobi "Druge Jugoslavije", već bih je samo iskoristio kao uvod i ostavio kao temu za daljnja propitkivanja i promišljanja razloga koji su jednu revolucionarnu partiju odveli s puta razvoja socijalizma. Ipak, u ovom istraživanju oslanjam se na jednu od devijacija koje su nastale kao nuspojava društvenopolitičke i ekonomske liberalizacije. Bili su to tehnokrati na čelu velikih poduzeća, koji su velikim dijelom zavladali jugoslavenskim poslovnim svijetom. Oni su iskoristili svaku vidljivu i skrivenu dvosmislenost zakonskih okvira samoupravno-tržišnog "socijalizma" kako bi ojačali moć svojih poduzeća, a nerijetko i vlastiti politički i materijalni položaj. Istovremeno, proizvod njihovog rada bili su veliki poslovni sustavi (VPS) u eri tržišne reforme i kasnije samoupravne kontra-reforme. Ta gigantska poduzeća-gradovi postala su perjanice ekonomije te gradila jugoslavensko industrijsko društvo, odnosno snabdijevala ga suvremenim načinom života.

Ova glavna teza rada otvara mnoga pitanja, od kojih na neka ne možemo u njemu odgovoriti. Naime, umjesto daljnjeg inzistiranja na teorijskoj analizi, ovo se istraživanje spušta na razinu mikrostrukture i promatra prvih petnaestak dinamičnih godina povijesti Građevnog kombinata Međimurje (dalje u tekstu GK) i njegovog suživota odnosno simbioze s lokalnom sredinom male općine Čakovec. Sinergija općine Čakovec i $G K$ među rijetkim je jugoslavenskim primjerima dosljedne pri- 
mjene ekonomskih postulata privredne reforme iz sredine 1960-ih. Također, slučaj tog poduzeća, iako očito vođenog (ponekad i radikalno) tehnokratskim metodama, jest takav da ono nije proživjelo nasilnu smjenu vodstva u vrijeme kontra-liberalnih kampanja u prvoj polovici 1970-ih. Ovaj članak dio je šireg istraživanja poslovne povijesti Jugoslavije; u bližoj budućnosti usporedit ću čakovečki gigant s jednim zagrebačkim poduzećem sličnog profila. No za sada će ovaj dio istraživanja ponuditi, između ostalog, definiciju velikih poslovnih sustava iz perspektive poslovne povijesti, ${ }^{2}$ ali i u uvjetima društvenog vlasništva, te kroz primjer čakovečkog $G K$ ispitati dinamiku sprege poslovnog i partijskog, odnosno veze između ekonomije i politike lokalne sredine na hrvatskoj periferiji. ${ }^{3}$ Budući da je Kombinat imao ključnu ulogu u ekonomskom životu cijelog Međimurja, ovdje se preispituju i dosezi VPS-ova, odnosno do koje mjere je jedna mikrostruktura utjecala na život druge $\mathrm{i}$ jesu li postojale jasne granice među njima.

Najrelevantniji izvori za istraživanje povijesti Međimurja u drugoj polovici 20 stoljeća iz perspektive njegovog najvažnijeg poduzeća svakako su arhiva poduzeća pohranjena u Štrigovi (HDA-DAM-205) te tvornički list GK Međimurje (GKM). Iako je arhiva $G K$ još uvijek potpuno nesređena, moguće je doći do najvećeg broja zapisnika i materijala za sastanke Radničkog savjeta i Poslovnog, odnosno Izvršnog odbora. Iako ne mogu dati potpun uvid u sam proces krojenja poslovne politike i svega što se odlučivalo iza zatvorenih vrata, zapisnici i dalje dovoljno vjerno svjedoče o samom tijeku materijalne ekspanzije Kombinata i o okvirima u kojima je djelovala njegova uprava. Mjesečnik i kasnije dvotjednik mijenjao se kroz 35 godina postojanja od krajnje funkcionalistički orijentiranih novina, koje se bave isključivo bitnim podacima za rad poduzeća, do medija koji se bavi širim pitanjima i promovira kontra-reformsku ideologiju. Budući da su novine bile informativno glasilo za radništvo, s poslovno-operativne strane list GKM korektno je izvršavao svoju funkciju. Metodološki gledano, tvornička novina je vrlo zahvalan izvor za onu poslovnu povijest koja nastupa s pozicije tržišnog normativizma, posebno za razdoblje od 1966. do 1972., s obzirom na to da se u novinama rijetko javljaju šumovi ideološko-obrazovne prirode kao što su, na primjer, tekstovi o povijesti NOB-a, o Partiji, o marksizmu i marksističkoj misli. Za razdoblje nakon 1972. novine i dalje nude pregršt osnovnih informacija o poslovanju, ali samoupravljanje dolazi u prvi plan te se mijenjaju i retorika i model prezentacije rada Kombinata.

2 Poslovna povijest (business history) nastala je kao dio anglosaksonske historiografije i do sada je okupila nekoliko generacija povjesničara primjenjujući i mijenjajući svoje metodološke i teorijske okvire. Usredotočuje se na povijest razvoja poduzeća i njihovih poslovnih metoda, razvoj poduzetništva i poslovne klime te utjecaj poslovnog svijeta na društvo u cjelini.

${ }^{3}$ Sjever Hrvatske, iako je bio među razvijenijim predjelima Kraljevine Jugoslavije, 1945. i dalje je spadao među pretežito poljoprivredne predjele u novoj Jugoslaviji. 
Ovaj članak podijeljen je u tri dijela. Prvi dio kontekstualizira velike poslovne sustave u teoriji poslovne historiografije, ali istovremeno nastoji utvrditi kako se jugoslavenski primjeri uklapaju u okvire postavljene od poslovne povijesti. Drugi dio objašnjava preduvjete u kojima se stvara $G K$, odnosno uvjete u kojima poduzeće započinje svoje izrastanje u regionalnog giganta. $U$ tom smislu, drugi se dio najviše oslanja na razdoblje od 1965. do kraja tog desetljeća, vrijeme kada uprava tehnokratskim mjerama organizira poduzeće prema tržišnim principima. Treći i najveći dio prati povijest brzog razvoja poduzeća kroz 1970-e i početak 1980-ih. U kontekstu tog perioda rasvjetljava unutarnje odnose u poduzeću, poslovne prilike i neprilike u doba stagflacije i, naravno, usku povezanost poduzeća s općinom Čakovec, koja poprima simbiotske osobine.

\section{Nastanak velikih poslovnih sustava i korporativnog upravljanja u svijetu i Jugoslaviji}

Prve konture velikih poslovnih sustava ocrtavaju se u Sjedinjenim Američkim Državama tijekom druge polovice 19. stoljeća, u trenutku kada se tamo integriraju željeznice i stvara potreba za departmentalizacijom i primjenjivanjem složenijeg upravljanja poduzećem (Chandler, 1963; Whitten, 2006). Po uzoru na željeznice vrlo brzo korporativni pioniri Du Pont, Standard Oil, US Rubber Industry, General Electrics i drugi implementiraju slične složene organizacijske sheme (Chandler, 1999; Cassis, 1997; Whitley, 1992; 1999). Uz supstancijalno političko zaleđe ti takozvani "nacionalni šampioni" ubrzano rastu i šire se te razvijaju tržišno štetne pojave kao što su regionalni monopoli i državni karteli protiv kojih federalna vlada intervenira posebnom zakonskom regulativom. Prema osnivaču poslovne povijesti, pozitivistu i predanom sljedbeniku američke škole modernizacijske teorije Alfredu Chandleru, moderno industrijsko poduzeće, da bi postalo veliko, mora prebroditi dječje bolesti razdvajanja vlasništva i profesionalnog upravljanja (Chandler, 1963), o čemu 1920-ih prvi teoretiziraju pravnici Adolf Berle i Gardiner Means (Berle i Means, 1969). Također, prema Chandleru, važan korak za ta poduzeća bilo je i sazrijevanje na polju poslovne strategije i strukture. Pod strategijom podrazumijevao je diverzifikaciju proizvodnje, odnosno širenje vlastitih proizvodnih interesa s osnovne djelatnosti na srodnu ili raznorodnu proizvodnju roba i usluga. Promjena u strukturi značila je organizacijsku intervenciju spajanja već integriranih tvornica i pogona u logične jedinice, odnosno već spomenutu departmentalizaciju.

Oba ta mikroekonomska fenomena mogu se prepoznati i u poslovnom svijetu Jugoslavije u drugoj polovici 20. stoljeća. S jedne strane, jugoslavenska interpretacija i praksa udruženog rada iz 1960-ih i 1970-ih u svojoj klasičnoj integracijskoj, a kasnije dogovornoj homogeno-atomizirajućoj logici pratila je donekle zapadne organizacijske modele. Međutim, sustavno okrupnjivanje istorodnih proizvođača $u$ 
grupacije, koje je nadilazilo okvire poslovnih sustava, u praksi je prkosilo tržišnim principima u kojima je politička elita željela da ta poduzeća egzistiraju. Upravo iz tog razloga doprinosi udruženog rada marginalizirani su u praksama rukovodstava poduzeća nakon 1978. godine kako bi poduzeća mogla nastaviti boriti se za svoje mjesto na tržištu. S druge strane, oblik razdvajanja vlasništva i upravljanja u Jugoslaviji događa se već sredinom 1960-ih kada kroz modernizacijske reforme velika poduzeća stječu dotada nezamislivu razinu autonomije u upravljanju prihodima, kapacitetima i investicijama te u krojenju poslovne politike. U procesu tog razdvajanja glavnu ulogu u poduzećima imaju uprave s timovima profesionaliziranih direktora. Zbog nezanemarive akumulacije političke, ali u prvom redu upravljačke i materijalne moći, njih kritičari negativnih rezultata tržišne reforme u javnom i političkom diskursu pežorativno nazivaju "tehno-menadžeri" ili "tehno-birokracija" (Deveti kongres, 1969: 144). U tom smislu ishitreno uvođenje ourizacije u 1970ima (Jović, 2003) jednim se dijelom može promatrati i kao odgovor na pojave štetne za ekonomiju društvenog vlasništva.

Udruživanje manjih ili srednjih poduzeća u velike ili složene poslovne sustave kao što je bio $G K$ nije bilo slučajno, niti je došlo kao prirodni tijek razvoja jednog jugoslavenskog poduzeća. Naprotiv, formiranje Kombinata bio je promptni odgovor čakovečkih komunista na poziv za političko-privrednu akciju objavljenu od najvišeg partijskog rukovodstva krajem 1962. godine. Naime, na IV. plenumu CK SKJ, koji je održan 22. srpnja 1962., partijski prvaci tražili su odgovor na vidljivu recesiju (AJ 507-SKJ-137). Pad stopa rasta doveo je do neugodnog otriježnjenja od teze o ekonomskom čudu materijaliziranom tijekom prethodnog razdoblja, za trajanja najuspješnije provedenog petogodišnjeg plana od 1957. do 1961. godine (Sirotković, 1989: 13). Međutim, Jugoslaviji su osim recesije došli na naplatu i krediti za koje se federalno vodstvo intenzivnije odlučilo sredinom 1950-ih umjesto dotadašnjih bespovratnih subvencija iz Washingtona, Londona i Pariza (Unkovski-Korica, 2016; Obadić, 2017). Krediti su bili primani u konvertibilnim valutama i povrat se, naravno, tražio u dolarima, funtama, francima i markama. Tvrde valute Jugoslavija je mogla prikupiti isključivo izvozom i turizmom, pa je stoga ekonomska politika s kraja pedesetih obilježena snažnom orijentacijom k ubrzanom multipliciranju ugostiteljskih objekata na obali i probijanju na međunarodno tržište (Duda, 2005; 2010; Obadić, 2017). Konkretniji prodor na zapadno tržište, međutim, nije bio nimalo lak zadatak jer je podrazumijevao značajnu promjenu u poslovnom mentalitetu i proizvodnji. Naime, poduzeća su bila primorana kvantitativno podići proizvodnju na višu serijsku razinu i istovremeno kvalitetom roba i usluga zadovoljiti minimalne standarde razvijenih zemalja. I dotada je postojala vanjskotrgovinska razmjena, ali nije ni približno zadovoljavala visoke apetite i akumulaciju koja je trebala Jugoslaviji. 
Modernizacija proizvodnog procesa podrazumijevala je osuvremenjivanje tehnološke opreme i uvoz znanja, uglavnom sa Zapada, za što je opet bilo nužno posjedovati devizna sredstva. U tim okolnostima, na početku 1960-ih, nastala je inicijativa za industrijskim okrupnjavanjem, odnosno integracijom u logički i ekonomski opravdane sustave, tj. kombinate. Da to stavimo u Titove riječi na spomenutom IV. plenumu, na koje su se kasnije pozivali manje-više svi integracijski elaborati u svojim uvodima:

Kada je riječ o orijentaciji naše proizvodnje na izvoz, treba reći da smo mi do sada osnivali mala poduzeća za izvoz. Što može mala fabrika? Kako ona može da konkuriše na međunarodnom tržištu? [...] Samo serijskom proizvodnjom jedna modernizovana fabrika... može da ide na inostrano tržište i da sa uspjehom konkuriše... Od sada mi moramo našu proizvodnju orijentirati na to da se razvijaju što krupnija poduzeća koja će biti i izvoznici i proizvođači, koja će svoje proizvode direktno da iznose na inostrano tržište. (AJ 507-SKJ-137)

Drugim riječima, tražila se raširena akcija sistemske vertikalne i horizontalne integracije, odnosno povezivanja sirovinske proizvodnje ili eksploatacije s prerađivačkom industrijom te izvedbom ili distribucijom proizvoda s ciljem stvaranja ekonomski racionalne cjeline. Klasičan primjer takvog okrupnjavanja postignut je 1964. spajanjem Naftaplina kao vodećeg eksploatatora naftne sirovine s rafinerijama u Sisku i Rijeci te na kraju s benzinskim crpkama tadašnjeg Croatiapetrola $\mathrm{u}$ Industriju nafte i plina poznatiju kao INA (“Impozantan razvoj”, Vjesnik INE, 28. prosinca 1970.).

Da bi se stvorila zajednica poduzeća s ekspanzivnom perspektivom i serijskom proizvodnjom, stručni timovi bili su zaduženi za pisanje elaborata o ekonomskoj isplativosti ili opravdanosti kako izgradnje potpuno nove industrije tako i integracije postojećih kompanija (Buković, 1964: 89). Političko-teritorijalna decentralizacija federacije iz 1960-ih omogućila je republičkim privrednim komorama da budu glavni medijatori i kontrolori spajanja, odnosno instance bez čijeg pristanka postupak fuzije nije mogao započeti. Međutim, budući da je stvaranje kombinata u nekoj sredini bilo i političko pitanje odnosa lokalnog centra prema vlastitoj ekonomiji, nerijetko su poduzeća u Jugoslaviji bila spajana bez uzimanja u obzir ekonomske racionalnosti, što je često stvaralo gubitaše i dovodilo do dezintegracije. Pa je tako u SR Hrvatskoj bilo primjera:

[...] spajanja ciglane s lanarom, projektne organizacije s novinsko-izdavačkom djelatnošću, s poljoprivredom, zadrugom i sl. U nekim se slučajevima pristupilo fuziji bez prethodnog rješenja personalnih pitanja (u novom velikom poduzeću ostalo je 6 direktora). To sve samo pokazuje da su takve fuzije vršene bez prethodnih potrebnih analiza. (ibid: 55-56) 
No $G K$ svakako nije bio jedan od tih primjera, dapače, njegova uprava pokazala se revnijom i dosljednijom u ispunjavanju zahtjeva nametnutih tržišnom reformom.

\section{Stvaranje $G K$}

Međimurje je dugo bilo mađarska periferija, ali s dominantno slavenskim stanovništvom, što je vjerojatno i bio razlog ekonomskog zapostavljanja te, u principu, resursima bogate sredine (Kalšan, 2006: 382-387). Nakon oslobođenja 1945. pripojena sjeverna regija vrlo je brzo doživjela stagnacijski udarac zbog razlaza sa Sovjetskim Savezom 1948. godine. Tada je velik dio ionako siromašnih industrijskih kapaciteta preseljen u Sisak i južnije u Bosnu i Hercegovinu te su nametnute oštre restrikcije na kapitalne investicije koje su potrajale sve do 1956. kada su Beograd i Moskva i službeno smirili političke tenzije. Stoga je taj kraj bio primoran osloniti se na poljoprivredu. Za pokretanje građevinske industrije u Međimurju, međutim, bilo je objektivnih argumenata jer je ta riječna regija imala nekoliko kompetitivnih prednosti. S jedne strane, u prilog građevinarstvu išle su višestoljetna zanatskoobrtnička tradicija tesara, zidara, stolara i drugih srodnih djelatnosti, ali i nezanemariva gastarbajterska kultura rada lokalnog stanovništva. Drugim riječima, postojao je viši prag tolerancije radnika na sezonsko izbivanje iz mjesta prebivališta zbog terenskog rada koji je bio karakterističan za srednja i velika poduzeća u industriji gradnje. S druge strane, pogodovalo je bogatstvo izvora sirovina kao što su glina, šljunak i pijesak, ključnih za proizvodnju kvalitetnog betona i cigle, koja će u 1970ima i poslije biti jedna od najlukrativnijih djelatnosti Kombinata ("Od cehova do kombinata", GKM, 15. studenog 1970.).

Građevni kombinat Međimurje započeo je s radom 1. listopada 1963. kada se ujedinilo nekoliko malih i srednje-velikih poduzeća iz Čakovca i okolnih sela. Horizontalnim spajanjem Građevnog poduzeća Čakovec i GP Graditelj te vertikalnom integracijom s tri stare ciglane iz poduzeća Naprijed sjedinile su se tri djelatnosti: projektiranje, eksploatacija sirovina, proizvodnja ili realizacija. U istom su valu pripojeni i Zanatski servisi, koji su zapošljavali nekoliko desetaka električara, vodoinstalatera, limara i strojobravara. Pri takvim integracijama politički akteri često su igrali ključnu ulogu, pogotovo ako je ona uključivala sjedinjenje više poduzeća iz različitih komuna. Premještanje centrale poduzeća značilo je odlazak svih prihoda tog poduzeća u neki drugi centar. Stoga je nerijetko iza svakog takvog uspješnog projekta stajao jedan autoritet s dovoljnom količinom političkog kapitala da može uvjeriti sve uključene strane u racionalnost ili nužnost integracije.

U čakovečkom slučaju to su bili međimurski partijski prvaci, a među njima istaknuo se Josip Horvat Zdelar, predratni komunist i nositelj Partizanske spomenice 1941. te prvi čovjek općine Čakovec i direktor jedne od budućih sastavnica (Da- 
nijel Režek, u razgovoru s autorom, 30. lipnja 2016.). Svojim zalaganjem zauzeo je i mjesto prvog direktora Kombinata, no njegova uprava bila je kratkog vijeka, jer je umro već 1966. godine (“Od cehova do kombinata”, GKM, 15. studenog 1970.). Zdelar je predstavljao tipičan profil "instaliranog" direktora, ${ }^{4}$ odnosno rukovodioca kojem su bez prethodnog iskustva ili znanja dodijeljene najviše upravljačke pozicije i u lokalnoj administraciji i u Partiji ili gospodarstvu (Fikfak i Prinčič, 2008: 104-135). No nedostatak kvalifikacija svakako nije značio i manjak poduzetničke inicijative, odnosno, kao što je to naglasio tadašnji tehnički direktor, a kasnije tehno-menadžer Danijel Režek:

GK Međimurje je bila komunalna firma, isto je imala puno tehničara, ali Šlibar i Kermek [političko vodstvo općine Čakovec] bili su dalekovidni i vidjeli su da bez inženjera mi ne možemo. Međimurje je bilo nerazvijeno, pokojni Zdelar, narodni heroj, on je bio direktor, koji je strašno uvažavao struku. On je vidio da tehničari vuku nazad. Nije bio školovan, ali je bio širih pogleda i Zdelar je nama dao podršku i doveo još inženjera i mogu reći da se GK Međimurje počelo polako razvijati. (Danijel Režek, u razgovoru s autorom, 30. lipnja 2016.)

Kao suprotnost Zdelaru, u GP Čakovec Režek je stigao odmah po završetku studija 1961., a u to doba bio je jedan od vrlo malobrojnih diplomiranih inženjera u općini. Mogućnost da se dobije diplomirani inženjer bila je toliko rijetka da su mu odmah dali dva radna mjesta istodobno. Njegova kvalifikacija poslužila je i kao potrebna garancija stručnosti za dobivanje licence novootvorene graditeljske škole. Nakon Zdelarove smrti, svojim prvim izborom direktora, što je zahvaljujući principu reizbornosti spadalo u domenu samoupravnih prerogativa poduzeća, radnički savjet odlučio se za Mirka Jageca, inženjera građevine sa završenom višom stručnom spremom i dugogodišnjim radnim stažem (Rajović, 1970: 381). Za razliku od svog prethodnika novi direktor je spadao u novu generaciju menadžera, takozvanih "penjača” koji su za razliku od "instaliranih" postepeno stjecali iskustvo i razvijali se savladavajući jednu po jednu stepenicu u hijerarhiji poduzeća ili partijsko-upravne administracije. Od sredine 1960-ih Partija je pokrenula sustavnu smjenu generacija u manje-više svim društvenim sektorima te je nastojala zamijeniti niskokvalificirana, ali lojalna rukovodstva iz revolucionarnih vremena što kvalificiranijim kadrom (Rusinow, 1977: 144).

\subsection{Početak tehnokratskog eksperimenta}

$G K$, naravno, nije imao strateški značaj, čak ni u lokalnoj zajednici, već je bio tek jedno u moru građevinskih poduzeća u Jugoslaviji i stoga nije mogao računati na

${ }^{4}$ Autor u svojoj doktorskoj tezi podrobnije razrađuje tipologiju direktora i njihovu podjelu na "instalirane" i "penjače", međutim, u trenutku objave ovog članka teza nije bila završena. 
značajniju materijalnu podršku izvan općine Čakovec. Iz tog je razloga za neku značajniju razvojnu perspektivu Kombinat bio primoran uglavnom se osloniti na vlastite potencijale i na kapacitete svog kadra. Rukovodstvu poduzeća u prilog je išla stečena autonomija poslovnih subjekata ostvarena novim Zakonom o poduzećima iz 1965., koja je svim akterima u ekonomiji supstancijalno odriješila ruke po pitanju kontrole prihoda, investicija te intervencija u strukturu i strategiju poduzeća (“Osnovni zakon o poduzećima”, Službeni list SFRJ, 17-354/1965). Jagec i Režek iskoristili su svaki milimetar novostečene poslovne emancipacije kako bi u Kombinatu pokrenuli tehnokratski eksperiment i ubrzali njegov razvoj. Nova uprava u osnovi se orijentirala na ekspanziju kroz rast profita i poslovnu logiku poznatu kao retain and reinvest (zadržati i ponovno uložiti) te proizvodnju baziranu na ekonomiji razmjera (O'Sullivan, 2000). Ipak, pokazalo se da su novi tržišni uvjeti u kontradiktornom odnosu s principima društvenih odnosa karakterističnim za socijalističku izgradnju.

Prateći reformska načela modernizacije proizvodnog procesa i prioritiziranja rentabilnosti, vodstvo je $G K$ 1966. otpustilo oko 250 radnika ili $20 \%$ ukupne radne snage koju su smatrali suvišnom, vjerojatno zbog neposjedovanja osnovnih kvalifikacija ("Dobar kadar...", GKM, 15. studenog 1970.). Povrh ekonomskih razloga, redovito su otpuštani radnici koji su ulovljeni u krađi, a posebnim disciplinskim mjerama kažnjavani su oni koji su zabušavali u poslu ili ga obavljali nekvalitetno kao što je to pošlo za rukom cijelom Taracerskom pogonu ("Radnički savjet...", GKM, 3. veljače 1967.). Zbog nerentabilnosti su taj pogon na kraju ugasili, kao i ciglanu u Mihovljanu čije su radnike onda prerasporedili po ciglanama u Šenkovcu i Belici ("Bez Mihovljana”, GKM, 16. prosinca 1966.). Nesnalaženje u nagloj promjeni poslovne kulture može se jasno iščitati upravo u sukobu između uprave i vodstva taracera. Rukovodstvo malog pogona, prozvano za nekvalitetan rad i gubitke, branilo se kako punih dvadeset godina nisu imali manjkove, a sada kada su se u samo dvije godine pojavili gubici, uprava poduzeća odmah ih želi zatvoriti ("Radnički savjet...", GKM, 31. ožujka 1967.). Direktor Jagec im je na to odgovorio da su se prvih dvadeset godina prihodi poduzeća gledali u svojoj ukupnosti, a da se sada valoriziraju za svaki pogon pojedinačno.

Nadalje, čistim računima i novim modelom raspodjele dohotka menadžment je nastojao riješiti akutni problem nedostatka visokokvalificirane i kvalificirane radne snage. U novogodišnjem intervjuu na samom kraju 1966. Jagec se osvrnuo na novi sustav dohotka u poduzeću i rekao:

Mislim da su, između ostalog, primanja više nego ikada dosada vezana za rezultate rada. Ako se sjećate, mi smo gotovo preko noći ukinuli tradicionalne promile pri plaćanju rukovodećeg tehničkog kadra. Ti su promili donosili ljudima dodatke prema vrijednosti objekta bez obzira kako se na njemu radilo, čak ako se i gubi. 
Sada su vezani za uspjeh rada kojim rukovode. Ne mogu reći da je u stimuliranju tih ljudi sve riješeno, ali je pravednije nego prije, i više potiče na bolje organiziranje posla. (“Imamo snage...", GKM, 30. prosinca 1966.)

Tako je, s jedne strane, novi model raspodjele dohodaka i bonusa možda motivirao postojeći kvalificirani kadar da ostane i istovremeno privlačio nove stručnjake da se zaposle u poduzeću skromnog profila kakvo je tada bio GK. Međutim, s druge strane, uprava je probijanje na tržištu iznijela na leđima većine kolektiva. Jeftine ponude za kapitalne projekte Kombinat je mogao ponuditi investitorima isključivo inzistiranjem na vrlo niskim plaćama, što je, naravno, najvećim dijelom zahvatilo nekvalificiranu i polukvalificiranu radnu snagu. Oni su, na primjer, u pogonu operative (graditelji), najbrojnijem u Kombinatu, činili čak polovicu ukupnog broja radnika (“Ozbiljno smanjena...", GKM, 31. kolovoza 1968.). Radi ilustracije, godine 1968. najniža plaća za četvrtinu nekvalificiranih radnika u poduzeću bila je cijelih 450 dinara (vidi tabelu 1), što je bila protuvrijednost od 36 dolara ("Satnice...", GKM, 16. rujna 1968.). Postavlja se pitanje zašto su radnici bez ozbiljnijeg otpora pristajali na jedna od najnižih primanja u sektoru građevine, ali i uopće u Jugoslaviji.

Tabela 1. Kretanje radne snage i kvalifikacijske strukture u $G K$ od 1967. do 1971. (“Kombinat od 1967. do 1971...”, GKM, 30. ožujka 1972.)

\begin{tabular}{|l|l|l|l|l|l|l|}
\hline Kvalifikacija & $\begin{array}{l}\text { Zaposleni } \\
\mathbf{1 9 6 7 .}\end{array}$ & $\begin{array}{l}\text { Osobni } \\
\text { dohodak } \\
\mathbf{1 9 6 7 .}\end{array}$ & $\begin{array}{l}\text { Zaposleni } \\
\mathbf{1 9 6 9 .}\end{array}$ & $\begin{array}{l}\text { Osobni } \\
\text { dohodak } \\
\mathbf{1 9 6 9 .}\end{array}$ & $\begin{array}{l}\text { Zaposleni } \\
\mathbf{1 9 7 1 .}\end{array}$ & $\begin{array}{l}\text { Osobni } \\
\text { dohodak } \\
\mathbf{1 9 7 1 .}\end{array}$ \\
\hline VKV & 50 & 755,40 & 79 & 990,70 & 121 & $1.494,20$ \\
\hline KV & 291 & 627,65 & 576 & 787,20 & 860 & $1.117,50$ \\
\hline PV & 179 & 530,10 & 359 & 638,95 & 398 & 891,80 \\
\hline NK & 216 & 438,65 & 510 & 533,75 & 603 & 784,40 \\
\hline VSS & 10 & $1.335,85$ & 24 & $1.741,45$ & 36 & $2.753,60$ \\
\hline VŠSS & 5 & $1.099,35$ & 7 & $1.545,60$ & 36 & $2.267,70$ \\
\hline SSS & 97 & 814,15 & 209 & 990,70 & 276 & $1.466,90$ \\
\hline NSS & 53 & 443,05 & 87 & 585,60 & 53 & 808,10 \\
\hline Ukupno & 901 & & 1851 & & 2383 & \\
\hline
\end{tabular}

Dio odgovora zasigurno leži u društvenoj i klasnoj pozadini većine radnika, koja je spadala u kategoriju "radnika-seljaka" ili "polutana", a koji su ili sezonski ili kroz cijelu godinu istovremeno radili na svojim imanjima i za poduzeće (Duda, 
2010: 298-299; Woodward, 1995: 43). S jedne strane, radom na vlastitim poljima uspijevali su zadovoljavati minimalne egzistencijalne potrebe, pa na prvi pogled nije bilo veće netrpeljivosti i nezadovoljstva. S druge strane, velik dio tih radnika proveo je cijeli život u izrazito skromnim uvjetima. Stoga je zaposlenje u $G K$ nakon godina provedenih na polju zapravo bilo prvi radni odnos, a to nedovoljno primanje često je služilo tek kao dodatna zarada za minimalno podizanje životnog standarda. Međutim, nakon privredne reforme troškovi života rast će puno brže nego što su to plaće mogle pratiti, a $G K$ će cijeli taj period do samog raspada uglavnom kaskati s razinom primanja. Također, ta podvojena lojalnost poljoprivredi i industriji utjecat će na sporije podizanje razine kvalifikacije među radnicima, a ujedno i efikasnosti poduzeća, odnosno produktivnosti rada. Zbog toga će uprava paralelno provoditi tehnološku modernizaciju proizvodnog procesa i stvarati infrastrukturu za obrazovanje radne snage (npr. izgradit će se Graditeljska škola u Čakovcu), a $G K$ će, što je možda najvažnije, graditi stanove u koje će ti radnici preseliti te ostaviti i selo i polje iza sebe.

U sferi modernizacije radnog procesa već krajem 1960-ih u Kombinatu su primijenjena nova znanja kako bi se doskočilo preprekama zastarjelog načina rada na terenu ovisnog o prihvatljivim vremenskim prilikama. Tako u prvim brojevima radničkih novina poduzeća tehnički direktor Režek piše kako će se poslovođe upoznati s tehnikama i pravilima korištenja građevnog materijala na niskim i nestabilnim temperaturama (“Građenje zimi”, GKM, 16. prosinca 1967.). Na taj način menadžment je značajno produžio radnu sezonu i na dio zimskog perioda, što će biti ključno za osvajanje jadranskog tržišta fokusiranog na turizam. $U$ to vrijeme ista promjena $u$ strategiji poslovanja primjenjivala se i u ostalim rastućim građevinskim poduzećima u Jugoslaviji. Drugim riječima, rukovodstva tih poduzeća općenito su pratila i integrirala stručna znanja ključna za intenzivno industrijsko poslovanje na tržištu.

Jedna od važnijih karakteristika novog profila $G K$ namijenjenog tržištu, na koju se od samog početka polagalo puno pozornosti, bilo je njegovanje reputacije pouzdanog i jeftinog izvršitelja poslova:

[Ušteda] je u ovom poslu naročito važna i zato što su uvjeti plaćanja relativno nepovoljni. Naime izgradnja nudističkog naselja u Rovinju prvi je posao integriranih poduzeća Generalturista iz Zagreba i Progresa iz Beograda. Sada je to organizacija koja će sigurno imati najveće financijske mogućnosti u turističkoj izgradnji, pa je prema tome itekako važno da se takvom investitoru predstavimo u najboljem svijetlu. ("U Istru...", GKM, 31. siječnja 1968.)

Rukovodstvo je pazilo na to da se svi ugovoreni poslovi izvršavaju u zadanom roku usprkos otežanim uvjetima financiranja, jer su izvođači radova bili primorani sami osigurati sredstva za provedbu projekta. Drugim riječima, u poslovnom fondu moralo je biti dovoljno sredstava za realizaciju projekata, a ona su se osiguravala "stezanjem remena" - naravno, u sferi plaća. Poslovanje Kombinata uz velika odri- 
canja na štetu standarda kolektiva koja su omogućila niže cijene prilikom projektnih licitacija te primjenjivanje suvremenih metoda izvedbe i nužnog volumena obrtnog kapitala postupno su mu otvarali vrata jugoslavenskog tržišta.

Glavni direktor Jagec komentirao je da je upravo privredna reforma iz 1965. godine bila prekretnica za $G K$ jer su tada prevladale "težnje da se iz pretežno lokalnih okvira izađe na jugoslavensko tržište" ("Dobar kadar... ", GKM, 15. studenog 1970.). Postići taj cilj nije bio nimalo lak poduhvat jer je poslovna arena u Hrvatskoj i Jugoslaviji bila poprilično zasićena građevinskim poduzećima. Gužvu na tržištu najbolje ilustriraju projektne licitacije, kao na primjer ona za izgradnju prodavaonice namještaja "Veleprometa" u Čakovcu iz 1967. godine. Tom prilikom natjecalo se šest poduzeća samo iz okolice Međimurja, a posao je na kraju pripao kolektivu $G K$ (“Dva posla...", GKM, 17. ožujka 1967.). Već spomenuto profiliranje poduzeća bilo je važno za održavanje koherentne poslovne strategije. Osim imagea važna je bila i uža specijalizacija, pa je poduzeće naglasak stavilo na visokogradnju, odnosno stambene višekatnice, hotele i industrijske objekte ("Jačati industrijsko...", $G K M, 15$. studenog 1970.). Kolaž tih raznovrsnih građevina podignutih u vlastitom "dvorištu" postao je portfelj koji se onda koristio kao kolaž referenci za probijanje na širem hrvatskom i jugoslavenskom tržištu.

Političkom inicijativom i imaginacijom lokalne administracije, doprinosima građana i realizacijom poduzeća Čakovec je započeo svoju metamorfozu iz obrtničko-trgovačkog naselja podno dvorca Zrinskih u moderan grad. Objekti kao novi hotel "Park" i proizvodna hala Međimurske trikotaže Čakovec (MTČ - druge najveće industrije u općini) te zgrada gimnazije, prostrana robna kuća i prvi stambeni soliteri, podignuti rukama radnika $G K$ u drugoj polovici 1960-ih, radikalno su transformirali izgled grada ("Novi objekti", GKM, 25. studenoga 1966.; "Rekordan rok...", GKM, 20. siječnja 1967.). Istovremeno u prosincu 1966. dio radnika odlazi u Pulu na svoj prvi zimski angažman gdje grade restoranski kompleks s bazenom na Zlatnim stijenama, i time integrirano poduzeće ostavlja svoj prvi trag na Jadranu ("U Pulu...", GKM, 25. studenog 1966.). Samo godinu dana nakon toga menadžment ponovno odlazi u Istru i dogovara svoj dotad najveći posao, vrijedan milijardu i 400 milijuna starih dinara za izgradnju turističkih kapaciteta u Rovinju i Umagu ("U Rovinj...”, GKM, 31. siječnja 1968.). Taj lukrativni posao na obali obilježit će početak silovitog uspona Kombinata koji će trajati bez prekida gotovo petnaest godina.

Pozitivni poslovni rezultati omogućili su modernizaciju pogona, pa se rukovodstvo orijentiralo na dotad najslabiju kariku, proizvodnju građevinskog materijala. Prvo su u ciglani u Šenkovcu sagradili novu sušaru koja je znatno povećala brzinu proizvodnje te promijenili tip goriva s krutih na tekuća, čime su se smanjili troškovi rada pogona (“Šenkovec bliži...", GKM, 16. rujna 1967.). No najveća investicija materijalizirala se u obliku specijaliziranog silosa za glinu, koji se u to vrije- 
me poistovjećivao s najsuvremenijom tehnologijom u Europi, rijetko prisutnom u Jugoslaviji. Godinu dana kasnije na red je došao Pogon prednapregnutog betona u koji se uložilo četiri milijuna novih dinara, zbog čega je i tim rukovodilaca otišao u Francusku potražiti najbolje moguće tehnološko rješenje ("PPB...", GKM, 25. siječnja 1969.). Investicija je usmjerena u pogonski transport koji se do tada vršio manualno, pa je izračunato da je samo 1968. oko 15 milijuna kilograma materijala preneseno rukama. Ulagalo se i u filtar za separaciju šljunka i u modernizaciju strojeva za proizvodnju betona, što je sve ukupno znatno ubrzalo samu proizvodnju. Poduzeće je tako dočekalo kraj desetljeća s tehnološkim osvježenjima i uspostavljenim poslovnim vezama na obali, spremno za širenje unutar i izvan granica općine Čakovec, na koju će svojim udjelom društvene reprodukcije u 1970-ima ostaviti još vidljiviji trag.

\section{Lokalni monopol u zlatno doba građevinarstva - 1970-e}

Već krajem 1968. pokazalo se da su ugovoreni poslovi počeli nadilaziti mogućnosti poduzeća, odnosno količina i opseg poslovnih angažmana postajali su sve zahtjevniji za njegove skromne kapacitete obrtnih sredstava. Financijske su poteškoće, međutim, velikim dijelom nastale i uslijed već spomenute promjene u kulturi građevinskog poslovanja, jer se za projekte više nije plaćalo unaprijed, nego po izvršenom poslu. Poduzeće je stoga u svojem poslovnom fondu prije samog početka izvedbe trebalo imati osigurana sredstva za izgradnju. Zato se Jagec iste godine žali na smanjeni poslovni potencijal te od lokalne zajednice i banaka traži pomoć kako bi mogli nastaviti rasti ("Rast plaća...", GKM, studenog 1968.). No muke neće predugo trajati jer je $G K$ već tada imao status lokalnog poslovnog heroja. Taj status isticali su i lokalni političari, kao na primjer dvije godine kasnije Ignac Bel, predsjednik Skupštine općine Čakovec, kad je na proslavi 25 godina postojanja poduzeća izjavio: "Povijest Kombinata ujedno je i povijest Čakovca i Međimurja". Što se tiče cjelokupne čakovečke suvremene povijesti, Bel nije bio predaleko od istine s obzirom na to da je $G K$ gradio sve najvažnije objekte u tom kraju ("Poticaj za...", GKM, 15. prosinca 1970.). No iz današnje se perspektive ta izjava više mogla shvatiti kao proricanje budućnosti nego kao refleksija na prošlost, jer vrijeme najintenzivnijeg rada Kombinata tek je nadolazilo.

Na samom početku desetljeća, 1970. godine, $G K$ je imao 200 milijuna dinara ukupnog prihoda i oko 2.200 zaposlenih, što ga je prema mjerilima velikih industrijskih sustava iz tog vremena još uvijek svrstavalo među provincijalna poduzeća srednjeg dometa ("Promet 20...”, GKM, 1. ožujka 1971.). ${ }^{5}$ No gledajući iz ugla ju-

${ }^{5}$ Prema kvantitativnim kriterijima koje sam postavio u doktorskoj tezi, poslovni sustavi u Jugoslaviji morali su imati 30 milijuna dolara ukupnih prihoda i tri tisuće zaposlenih da bismo ih tretirali kao velike. 
goslavenske građevinske industrije, te je godine samo GK Komgrap iz Beograda sa 688 milijuna dinara prihoda i 4.200 radnika ispunjavao kriterije velikog poslovnog sustava u Jugoslaviji ("100 najvećih...”, EP, 20. 9. 1971.). Ostatak desetljeća, međutim, obilježilo je bujanje moćnih kombinata, osobito građevinske industrije koja je kapitalizirala na političkoj decentralizaciji i nekontroliranoj investicijskoj politici lokalnih sredina, ali i drugih velikih firmi. Slijedom takvih kretanja jugoslavenski je poslovni svijet 1978. imao četrnaest giganta u građevinskoj industriji, a svaki od njih doprinosio je s minimalno tri milijarde dinara ukopnog prihoda i brojao preko tri tisuće zaposlenih radnika (“140 najvećih...”, EP, 29. listopada 1979.).

Kombinat je odmah nakon prvih uspješnih poslovnih godina razvio poseban odnos simbioze s rukovodstvom općine Čakovec. Da se čakovečka politika poprilično uzdala u $G K$ vidjelo se u njezinim odlukama da se ostalim građevinskim i srodnim poduzećima ne pomaže $u$ investicijama za kapitalnu gradnju. Umjesto toga, odluku ima li smisla, primjerice, pilanu modernizirati ili integrirati s Kombinatom prepustila je kolektivu lokalnog "šampiona", i tako je pilana bila pripojena ("Komunisti o integraciji”, GKM, 31. kolovoza 1968.; "Pilana...", GKM, 30. rujna 1968.). Međutim, u pravilu nekontrolirane investicije bile su jugoslavenska politička i ekonomska bolest, koja se osobito razvila nakon dodjeljivanja autonomije poduzećima jer su se ona često na svoju ruku zaduživala kod banaka i često širila vlastite kapacitete neopravdano ili bez jasne računice o isplativosti ulaganja. Taj negativni sindrom u 1970-ima donijet će velike zastoje u prometu društvenih sredstava.

Prije nego se Kombinat uspio opustiti u materijalnom blagostanju dogodila se prva kriza proizašla iz sindroma prebrzog širenja. Cijena ekspanzije bila je plaćena padom produktivnosti rada jer se napustio mentalitet štediše iz prošlog desetljeća. Direktor Jagec je 1970. na prvoj sjednici novoformiranog Poslovnog odbora izrazio oštru kritiku na račun "Građevne operative", glavnog nositelja poslovanja firme, jer je zapala u dugove:

Od nekadašnjeg poleta došli smo u situaciju da se ozbiljno zamislimo. Cijena koštanja, to jest troškovi, veoma nam brzo rastu. Tome je u velikoj mjeri kriva aljkavost na radu - ne pazi se svaki dinar. Isplaćuju se i nezarađeni osobni dohoci. U našim radnim jedinicama ima sve manje reda, svaka od njih, pa i svako gradilište, je nekakva republika za sebe, što je u modernom načinu privređivanja neodrživo. (“Prva sjednica...", HR-DAM-205, 6. kolovoza 1970.)

Nastavio je o vrijednosti rada i primanjima u pojedinim pogonima:

Stimulacije dobrih radnika nam manjka. Sve plaćamo skoro podjednako, a to ne vrijedi. Satnica se daje i za nerad [...] Projektni biro ima visoke osobne dohotke. Ako su oni rezultat stvarnih efekata to je samo za pozdraviti. Međutim, treba vi- 
djeti da li su normativi u redu i da li je obavljen posao kvalitetan. Projektante treba spustiti na zemlju, kako bi radili kvalitetnije. U tom slučaju neka budu i velika primanja. (ibid.)

Nakon salvi kritike na račun manje-više svih odjela, kojih je sada već bilo preko deset, na spomenutoj sjednici Poslovnog odbora zaključili su da je zavođenje radne discipline i odgovornosti lajtmotiv narednih zadataka. Također, u strukturnim problemima poduzeća rukovodioci su pronašli opravdanje za redovito mjesečno sazivanje Poslovnog odbora. Poslovni odbor bio je najizraženiji izraz formalizirane centralizacije upravljanja u najužu moguću točku, odnosno upravljački sustav poduzeća sastavljen isključivo od najviših rukovodilaca. Takva koncentracija moći odlučivanja bila je u izravnoj suprotnosti s principima samoupravljanja, a pojavila se kao nova poslovna praksa (i zakonita mogućnost) dvije godine ranije s kontroverznim ustavnim Amandmanom XV. (Ustav sa ustavnim amandmanima, 1971). Ironično, taj novi prerogativ trebao je emancipirati samoupravljanje u radnim organizacijama na način da svaki radnički savjet samostalno odlučuje o unutarnjoj arhitekturi poduzeća, a umjesto toga pretvorio se u još jednu tehnokratsku devijaciju. Umjesto daljnje demokratizacije upravljanja, na površinu je isplivalo pravo stanje radničke samoupravne svijesti i odnosa moći između uprave i radnika. ${ }^{6}$ Drugim riječima, menadžeri (poslovna elita) "uvjerili" su radničke savjete u nužnost formiranja poslovodnih odbora, pa su na samom kraju 1960-ih ta tijela postala gotovo obavezna (ili su se učestalo pojavljivala) u statutima poduzeća. Upravo poslovni ili poslovodni odbori bit će kasnija točka prijepora i dokaz postojanja tehno-menadžerskog upravljanja (ili vladanja) poduzećem, te će stoga nakon 1974. i “oourske" kontra-reforme uglavnom nestati iz velikih poslovnih sustava.

Pored opuštenosti nižih razina menadžmenta i radnika poduzeća kroničnu migrenu upravi $G K$ stvarala je nelikvidnost, koja se ustalila kao dio poslovne kulture u Jugoslaviji od kraja 1960-ih. Praksa prema kojoj izvođači radova financiraju sirovine i izvedbu, a investitori plaćaju po završetku radova gurnula je Kombinat u nezavidan položaj. Neki investitori i kupci nisu mogli platiti, a velika poduzeća često su i imala sredstva, ali nisu prioritizirala podmirivanje obaveza prema vjerovnicima po izvršenoj prodaji robe ili usluge ni nakon 90 dana od predviđenog zakonskog roka ("Treća sjednica PO”, HR-DAM-205, 3. listopada 1970.). Koliko je to bio raširen problem istaknuo je i voditelj računsko-analitičkog odjela poduzeća (računovodstvo) na sjednici PO na kraju 1970. godine:

U neriješenim depozitima i okončanim obračunima zaleđeno je blizu 700 milijuna starih dinara, pa nam tu leže zamrznuta velika sredstva. [...] Čini mi se da ulazimo

${ }^{6} \mathrm{O}$ kontradiktornostima samoupravljanja u Jugoslaviji i odnosima radnika i uprave pisali su brojni sociolozi tog vremena (Županov, 1967; 1985; Supek, 1974). 
i u neke dubiozne poslove, radimo s onim investitorima koji nisu u stanju platiti ugovorene obaveze. Zato bi na tom planu ubuduće trebali biti oprezniji. Tako sada imamo situaciju da kreditiramo investitore čak s 1,3 milijardom s. d., a to bitno utječe na pomanjkanje obrtnih sredstava. (ibid.)

Kao odgovor PO je formirao "ekipu trenutka" koja je dobila zadatak da "sjedne na poslove nelikvidnosti", odnosno da vrši pritisak na kupce i investitore kako bi ih natjerali da plate dugovanja. Kroz cijelo desetljeće problem nelikvidnosti morit će jugoslavenski poslovni svijet u kojem će postati uvriježena praksa poslovati uz prisilu, odnosno ugovorne obaveze izvršavat će se putem naredbi sudova i blokada računa (Woodward, 1995: 229; Rusinow, 1977: 251). Tako je $G K$ za 1970. planirao polovicu od 11.489,000 dinara kojima su kreditirali Jadran Rovinj, Soko Mostar, Mljekaru Varaždin, Agroservis Čakovec i Stambeno poduzeće Čakovec naplatiti sudskim putem ("Peta sjednica PO”, HR-DAM-205, 5. studenog 1970.). Međutim, osim što je $G K$ imao dužnike, i samo poduzeće imalo je vrlo visoku stopu nepodmirenih potraživanja koja su se rješavala preko sudova:

Broj tužbi bio je velik i ranijih godina, ali posljednji mjeseci pokazuju još veću učestalost takvog načina naplaćivanja. Do kraja kolovoza sudskim smo putem prisiljeni da isplatimo 8,8 milijuna dinara ili 16,53 posto od ukupnih naših plaćanja. Zabrinjavajuće je i to da ovaj iznos predstavlja više od polovice ovako naplaćenih potraživanja čitavog Međimurja. ("Poslovi, nelikvidnost...", GKM, 10. rujna 1971.)

Dok je savezna vlada Džemala Bijedića makroekonomskim intervencijama poput devalvacije dinara bezuspješno vodila bitku sa "stagflacijom" (nepovoljnom kombinacijom recesije i inflacije), a Edvard Kardelj pripremao ourizaciju kao samoupravni odgovor na krizu, menadžment $G K$ zavodio je novu disciplinu. Jagec i društvo na čelu Kombinata na ourizaciju i puzeću ekonomsku krizu gledali su kroz vizuru tržišnog normativizma uz dozu ravnodušnosti prema najavljenoj atomizaciji:

Spomenuto je pitanje internih akata. Oni nam stvarno nedostaju, ali budimo načistu da nam nikakvi pismeni akti neće osigurati bolje poslovanje. To ovisi isključivo, najviše o samim ljudima. [...] Besparica je objektivna, vanjska situacija. Zbog toga treba iskoristiti sve unutarnje mogućnosti da to ublažimo. [...] Dobro organizirano gradilište daje brzo dobre efekte. ("Zajednička sjednica Odbora za odnose iz udruženog rada i PO”, HR-DAM-205, 30. srpnja 1971.)

Režek je u nastavku nadopunio Jageca i produbio njegovu misao posredno potkopavajući osnovne principe planske ekonomije:

Investitoru treba dati više prijedloga na izbor. Ako mu ne nudimo što hoće on odlazi drugdje. Kalkulacije su previše činovničke. Svako područje podnosi druge cijene. Zato treba raditi prethodne analize projekata. Ako možemo nešto supstitu- 
irati to treba uraditi ako je jeftinije, tehnološki jednostavnije. Treba nam razvojni centar, ali konkretan, prilagođen našim uvjetima. Da polazi i od kalkulacija i spušta neke stvari "na zemlju"... u naše tržne uvjete i tehnologiju. Operativu treba konstituirati kao nosioca posla. Trebamo iskoristiti naše kompetitivne prednosti. (ibid.)

Osim toga, menadžment je kroz drugu polovicu 1971. prepoznao da su sve brojniji vanjski kooperanti postali teret za poslovanje te si je postavio cilj njihovog radikalnog smanjivanja i prenošenja što je više moguće poslova na vlastite kapacitete (“Četvrta sjednica PO”, HR-DAM-205, 5. studenog 1971.). Također je sustavno dijagnosticirao probleme skenirajući jedan po jedan odjel. Ivan Vukšić iz računsko-analitičkog odjela za svaku sjednicu Poslovnog odbora dostavljao je analize svake radne jedinice, koje bi onda pratila komisija stručnjaka i tražila razloge pada efikasnosti rada (ibid.). Nakon višemjesečnih rasprava fokus se usmjerio na sam motor poduzeća - Građevnu operativu $(G O)$, jer joj je profitabilnost bila jako niska, pa je Režek predložio promjenu vodstva odjela. Umjesto dotadašnjeg kvalificiranog rukovodioca novi direktor $G O$ postao je mladi i dokazani inženjer Dragutin Matotek (ibid.). Drugim riječima, Jagec i Režek htjeli su profesionalizirati srednji menadžment ili, njihovim riječima, "stvoriti ekipu mladih i dinamičnih ljudi, neopterećenih nizom dosadašnjih odnosa, ali ljudi koji su već dosada dali određeni kvalitet - pokazali su stalnu brigu za dohodak" (ibid.). Zanimljivo je primijetiti kako je prilikom njihovog profiliranja poželjnog rukovodioca nestala dotada neizostavna varijabla "društveno-moralnih" kvaliteta, odnosno iskustvo političkog rada odgovorne osobe. S druge strane, "briga" za profit postala je relevantna, ako ne i presudna kategorija.

Zavođenje nove discipline kako bi se prevladala kriza očitovalo se u tehnokratizmu prilikom reguliranja odnosa u proizvodnom procesu. Uvođenjem radnih naloga radi potpune sistematizacije rada na terenu, ali i valoriziranja učinkovitosti svakog radnika išli su do algoritamskih krajnosti društveno-alijenirajućeg tehnicizma. U listu Kombinata ovako su opisali značaj nove radne dokumentacije:

Dva su najvažnija cilja novih radnih naloga [...] Prvi je cilj da svaka brigada, grupa radnika, pa dakle i svaki radnik, tačno zna unaprijed svoj radni zadatak i iznos što će ga dobiti za neto plaću kada taj zadatak izvrši, odnosno da tačno zna ostvarenu zaradu nakon obavljenog posla. Drugi je cilj posredan, a sastoji se u tome što će čisti računi u plaćanju svakog rada pobuditi interes svake brigade da ne trpi aljkav rad ili nerad nekog od svojih članova, jer će biti jasno da nerad jednog radnika smanjuje zaradu i svih drugih. (“Za čiste račune”, GKM, 15. siječnja 1971.)

Drugim riječima, motivaciju za efikasniji rad među radnicima nastojali su ukorijeniti u novčanoj stimulaciji i sustavom kolektivnog kažnjavanja aljkavosti koji 
bitno utječe na međuljudske odnose u kolektivu. U prilog tome da se cjelokupni poslovni diskurs uprave Kombinata koncentrirao na velike dinarske iznose, govori i činjenica da se prilikom raznih objava financijskih rezultata, visina osobnih dohodaka ili suma proizašlih iz ugovorenih poslova kontinuirano inzistiralo na korištenju starog obračunskog leksika. Tako su punih deset, pa čak i petnaest godina nakon izvršene denominacije jugoslavenske valute vrijednosti izražavane u "starim dinarima" jer su se na svaki iznos dodavale nule, što je u novinskim naslovima često mijenjalo milijune u milijarde ("Poslovi vrijedni...", GKM, 15. 11. 1970.).

Očekivano, zavođenjem discipline i organizacijom rada na principima "ekonomske racionalnosti" brzo su se postigli traženi rezultati i pojačala ekonomska moć poduzeća, što je otvorilo put za daljnju ekspanziju i tehnološku modernizaciju. Na samom kraju 1970. otvorena je nova pilana u Čakovcu kao centrala tvornice tesarsko-stolarsko-pilanskog servisa, a u nove hale smješteni su moderni strojevi zapadnonjemačke firme Esterer ("Nova pilana...", GKM, 15. siječnja 1971.). U potrebi za tehnološkim osvježenjem proizvodnje građevinske sirovine zbog povećane potražnje opeke nađen je glavni razlog zašto su pogledi uprave, zagrebačkih bankara i čakovečkih političkih prvaka sada bili okrenuti prema Šenkovcu i tamošnjoj ciglani ("Počela priprema...", GKM, 4. lipnja 1971.). Udruženim financijskim snagama pokrenuli su dotada najveću gospodarsku investiciju u povijesti Međimurja od 10 milijuna dinara i 9 milijuna deviznih dinara za uvoz tehnologije. Nakon pune dvije godine, sredinom 1973., otvorena je ciglana s najsuvremenijom proizvodnjom koja je dosezala 35 milijuna komada opeke godišnje, odnosno čak dvostruko više nego prije amortizacije (“Nova ciglana...”, GKM, 20. srpnja 1973.).

Modernizacija nije bila slučajna ni naprasni hir menadžmenta, već rezultat pomnije kontemplacije nad tržišnom potražnjom i mogućnostima ponude. U povećanoj potrebi za uvozom opeke iz Austrije, Mađarske, Poljske i Rumunjske uprava je vidjela priliku za osvajanjem lokalnog tržišta građevinskog materijala ("Počela priprema...", GKM, 4. lipnja 1971.). Naime, popisi stanovništva utvrdili su da više od 12 tisuća radnika boravi na tzv. "privremenom radu" na Zapadu u zemljama s tvrdom valutom (ibid.). Također, direktori GK saznali su za istraživanja koja su pokazala da kod gastarbajtera "devizne uštede kreću [se] godišnje oko nekoliko desetaka milijardi starih dinara" te da je petina tih ušteđevina upravo namijenjena "adaptacijama i popravcima postojećih stanova", a čak četvrtina za izgradnju novih kuća (ibid.). Osim toga, oni na radu u inozemstvu nadišli su skromnost međimurskog životnog standarda i mogli su si priuštiti gradnju kuće u kojoj bi se "feudalna zajednica" od nekoliko nuklearnih obitelji osjećala ugodno u tri, četiri i više spavaćih soba.

Kao što je to već predvidio predsjednik skupštine Bel, rast $G K$ bio je usko povezan s razvojem općine Čakovec. Simbolički se vrijeme početka izgradnje soci- 
jalnog blagostanja općine može vezati uz već spomenuti 25 . rođendan poduzeća. ${ }^{7}$ Tom su prilikom predstavnici obje strukture, poduzeća i općine, zajedno položili kamen temeljac za novu prostranu bolnicu na 12.000 kvadratnih metara ("Poticaj za...", GKM, 15. prosinca 1970.). GK nije samo gradio bolnicu, već je "upisom zajma i kreditiranjem" sudjelovao "kao društveni faktor od izuzetnog značaja" za cijelu sredinu (ibid.). Drugim riječima, Kombinat je našao svoje mjesto kao poluautonomna društveno-ekonomska struktura unutar općine, te su one zajedno stvorile povoljan simbiotski odnos. Na samom početku školske godine 1971./1972. jedan od dva međimurska narodna heroja, Karlo Mrazović-Gašpar, učenicima i nastavnicima predao je na korištenje Treću osnovnu školu (“Zgrada III. osnovne...”, GKM, 10. rujna 1971.). Kao dio tog kompleksa sagrađena je i "specijalna” škola za djecu s posebnim potrebama, što je u svakom slučaju bio odraz visoke razine socijalne osjetljivosti općinskog rukovodstva, jer u to vrijeme specijalna škola još nije bila uobičajena pojava u svakoj općini.

Osim bolnice i škole, sredinom 1973. izniknule su nove upravne zgrade $M T \check{C}$-a i Komercijalne banke te nova generacija stambenih zgrada u Strossmayerovoj ulici i u blizini gradskog parka (“Izgradili smo...", GKM, 27. lipnja 1973.). Osim izravnog sudjelovanja u podizanju životnih mogućnosti cijele općine, odnosno gradnje stanova "za tržište", $G K$ se u period između Pisma ${ }^{8}$ i novog ustava intenzivnije uhvatio ukoštac s rješavanjem stambenog pitanja vlastitih radnika ("Počinje izgradnja...”, GKM, 8. ožujka 1973.). Pored izravnog dodjeljivanja stanova, radnici su se mogli prijaviti za povoljne kredite namijenjene za "individualnu stambenu izgradnju” (“Kredite dobilo...”, GKM, 20. lipnja 1973.). Međutim, postavlja se pitanje do koje mjere je podizanje standarda radnika bila demonstracija socijalno osviještenog poslovanja velikog i uspješnog poduzeća, a koliko je to zapravo bilo slušanje direktiva Partije nakon otriježnjenja od nuspojava tržišne reforme početkom desetljeća? Da bi se dobio neki empirijski odgovor, valjalo bi u svakom slučaju istražiti koliko su veliki poslovni sustavi ulagali u vlastitu stambenu izgradnju prije i nakon 1972./1973. godine.

Kao manje-više svi veliki poslovni sustavi u Jugoslaviji $G K$ je na početku 1970-ih prolazio kroz pokušaj stabilizacije zbog nelikvidnosti i pomanjkanja obrt-

${ }^{7}$ Građevno poduzéce Čakovec osnovano je 1945. i njegove godine postojanja pribrojene su godinama postojanja Kombinata.

8 "Pismo" iz 1972. jedan je od poznatijih povijesnih dokumenata bivše Jugoslavije, a sadržavalo je Titovu kritiku rada SKJ uslijed društvene, političke i ideološke krize jugoslavenskog socijalističkog projekta koja je kulminirala preizraženom ekonomskom liberalizacijom i tzv. Hrvatskim proljećem. Iako nije imao obvezujući karakter, dokument je odmah poslužio partijskim aktivistima i raznim državnim službama kao relevantna referentna točka za smjene provođene u narednim godinama. 
nih sredstava ("Stabilizacioni program”, GKM, 11. siječnja 1973.). No Kombinat je unatoč tome doživio značajan uzlet. To su prepoznale Privredna komora Hrvatske i Služba društvenog knjigovodstva, te su 1971. svrstale poduzeće u klub 100 najuspješnijih u Hrvatskoj prema ostvarenom ukupnom prihodu ("Među 100...", $G K M$, 18. prosinca 1971.). Te rezultate $G K$ je ostvario djelovanjem na već probijenim tržištima, ali i osvajanjem novih. Po završetku velikih poslova u Rovinju i Umagu na izgradnji hotela "Aurora" i smještaja u turističkom naselju "Polari" Kombinat je utvrdio svoje mjesto u Istri ("Rovinjska iskustva", GKM, 1. srpnja 1971.). U isto vrijeme menadžment se izborio za nekoliko važnih poslova u najvećem hrvatskom gradilištu, ugovorivši izgradnju stambenih zgrada u Prečkom i prvu suvremenu garažu na sedam katova u Šubićevoj, te je tako progurao $G K$ u Zagreb (“Zagreb sve...”, GKM, 30. kolovoza 1971.). A onda je sredinom 1974. u kombinatskim novinama zabljesnuo naslov da je poduzeće ugovorilo dotad najveći posao 9 na izgradnji hotela "Belvedere" u Dubrovniku, vrijedan čak 50 milijuna dinara ("U Dubrovniku...”, GKM, 25. listopada 1974.).

Još jedan prijelomni trenutak, i za Kombinat i za lokalnu sredinu, bilo je formiranje OOUR-a Plin 1974., koji je iste godine započeo s plinofikacijom općine Čakovec ("Radnički savjet", HR-DAM-205, 2. srpnja 1974.). Izgradnja plinovoda iz Varaždina i stvaranje mreže bio je još jedan od vidova zajedničke modernizacije općine i Kombinata (“Izvještaj o poslovanju”, HR-DAM-205, veljača 1975.). S jedne strane, novi OOUR pobrinuo se da do 1975. plin bude dostupan kućanstvima, u prvom redu u zgradama koje su se u tom trenutku gradile. Tako je GK odmah tražio spajanje na plin takozvanih "stanova solidarnosti", ${ }^{10}$ a poduzeće je otkupilo 47 takvih stanova za svoje radnike. Na radnicima je bilo da si osiguraju aparate za kuhanje i grijanje, što je, naravno, ovisilo o individualnim mogućnostima. S druge strane, novoopremljena ciglana u Šenkovcu jedva je dočekala da zamijeni teški mazut značajno jeftinijim visokokaloričnim plinom, koji je bitno smanjio troškove proizvodnje (ibid.). Drugim riječima, sredinom 1970-ih GK plinofikacijom demonstrira svoju materijalnu moć koja je gotovo uvijek istovremeno podizala i ekonomski standard poduzeća, ali i standard života u općini.

Godine 1974. s promjenama koje su donijeli ustavni amandmani i ustav mijenja se i organizacija poduzeća te, kako je ranije najavljeno, nestaje Poslovni odbor i zamjenjuje ga Izvršni odbor radne organizacije, a direktor gubi mjesto stalnog člana te dolazi na sjednice kao promatrač koji sudjeluje u radu ("Sjednice RS i IO",

${ }^{9}$ Zbog inflacije i ubrzanog pada vrijednosti dinara čak je i analitičkom odjelu $G K$ bilo teško uspoređivati vrijednosti i razmjere vrijednosti poslova u raznim razdobljima, međutim, sigurni su da je "Belvedere" bio među onima u najtežoj kategoriji.

${ }^{10}$ Plaćenih sredstvima iz općinskog Fonda solidarnosti prikupljenih posebnim poreznim dotacijama. 
HR-DAM-205, 25. svibnja 1974.). Takve nominalne reorganizacije vršile su se širom Jugoslavije, ali stvarna arhitektura organizacije i upravljanja poduzećem ostajala je vrlo centralizirana. Iako je direktor imao nešto suzdržaniju ulogu na sjednicama, referenti pojedinih točaka dnevnog reda ostali su manje-više nepromijenjeni predstavnici menadžmenta. Neka vrsta formalne zamjene za Poslovni odbor bili su "sastanci rukovodilaca OOUR-a" s predsjednicima radničkih savjeta i sekretarima osnovnih organizacija Partije, na kojima se raspravljalo o važnim programima kao što su bili, primjerice, godišnji "planovi za poslovanje" ("Sastanak rukovodilaca OOUR-a”, HR-DAM-205, 25. siječnja 1975.). Pored predstavnika Saveza komunista koji ponovno postaju relevantan glas u organizaciji, javljaju se i nova tijela kao Odbor samoupravne radničke kontrole, preko kojeg su radnici dobili mogućnost nadzora svih proizvodnih procesa u poduzeću (“Sjednica RS”, HR-DAM-205, 23. prosinca 1974.).

Financijski odbor (FO) utvrdio se kao čuvar sve prekarnijih obrtnih sredstava, koja su u to vrijeme često ovisila o osiguranim poslovima u tekućoj godini. Tako je, na primjer, 1975. dobiveni avans za veliki posao u Dubrovniku nakratko izvukao poduzeće iz neizvjesnosti, a FO je ozbiljno sugerirao suzdržavanje od novih kredita i što bržu prodaju nakupljenih zaliha po skladištima (“Sjednica FO”, HRDAM-205, 19. ožujka 1975.). Kao što je nelikvidnost bila financijska glavobolja poslovnog svijeta, rastuća nezaposlenost predstavljala je društveno-ekonomski i politički problem, pa je država tijekom cijelog desetljeća vršila pritisak na poduzeća da povećaju broj novih radnih mjesta. Općina Čakovec tražila je od organizacija udruženog rada u svojem dvorištu da se usklade s opće-društvenim interesima (“Sjednica RS", HR-DAM-205, 5. studenog 1975.). Da bi ispunio taj zahtjev, $G K$ je morao balansirati između prekomjernog zapošljavanja i neprestanog ulaganja u kapitalnu izgradnju s jedne strane i modernizacije proizvodnog procesa koja je smanjivala potrebu za postojećim radnicima s druge strane ("Sastanak rukovodilaca OOUR-a", HR-DAM-205, 25. siječnja 1975.). Drugim riječima, tržišno i socijalističko-samoupravno usmjerenje sudarali su se po tko zna koji put u svojim fundamentalno oprečnim principima i pokazivali međusobnu nespojivost.

\subsection{Strukture u simbiozi}

Kombinat svojim rastom nije samo postao izvor materijalno-društvene reprodukcije i moći koja doprinosi općem standardu već se postavljao i kao značajan politički subjekt, koji sada kroji stavove jednog dijela radno aktivnog stanovništva. $\mathrm{Na}$ primjer, kad su pred zimske praznike u prosincu 1970. prosvjetne radnice i radnici pokrenuli štrajk i na pet dana zatvorili vrata za 17.000 učenica i učenika, Kombinat je zauzeo čvrst stav. Naime, pobunjeni su istaknuli zahtjeve za usklađivanjem ili barem približavanjem njihovih dohodovnih koeficijenata s onima iz ostalih profesija 
s visokim obrazovanjem ("Protiv metode...", $G K M$, 15. siječnja 1971.). Međutim, umjesto solidarizacije u "radničkoj državi", u listu GKM izašao je članak površnog razumijevanja zahtjeva, ali usmjeren protiv metoda takozvane "obustave rada" i pritiska na "prenapregnuti" općinski budžet (ibid.). Radilo se o svega 2,6 milijuna dinara za povećanje plaća od $15 \%$ za sve prosvjetne radnike u Međimurju koji su u razdoblju nakon donošenja reformi kao i svi ostali osjetili nerazmjeran porast cijena u usporedbi s dohocima. Srećom po prosvjetare, najveći kolektivi u općini nisu se složili sa svojim upravama te su odbili sudjelovati u stvaranju pritiska na štrajkaše.

No ilustrativniji primjer prelijevanja dviju struktura mogao se iščitati u njihovom međusobnom kadrovskom prestrojavanju sredinom 1970-ih. Ovaj put, umjesto prelijevanja iz općine u poduzeće, kao što je to bio slučaj kada je Zdelar prešao iz Skupštine u Kombinat, poslovni svijet zavladao je politikom. Za mjesto predsjednika Skupštine Općine 1974.-1978. kandidirao se i bio izabran dotadašnji visokopozicionirani član tehno-menadžerskog tima poduzeća Danijel Režek ("D. Režek...", $G K M, 27$. travnja 1974.). Režek je za općinu imao velike planove koje je najavio i u svojem prvom intervjuu. Istaknuo je da će tekstilna industrija i poljoprivreda dobiti novi vjetar u leđa na osnovi modernizacije, dok je svojoj grani namijenio istu dominantnu poziciju:

Mislim da je trenutak kad upravo građevinarstvo treba navijestiti period realizacije ambicioznijih projekata, jer ako građevinari neće graditi na ovom području, neosporno je da će i ostale privredne grane stagnirati - a to nitko ne želi, niti pak su okolnosti takve da bi se stagnacije trebali pribojavati. ("Građevinarstvo...", GKM, 28. lipnja 1974.)

A četrdesetak godina kasnije u intervjuu s autorom ovog članka, prisjećajući se svojih početaka u koži prvog čovjeka općine, Režek je naveo kako je u svim odjelima općinske uprave zavodio isti tehnokratski režim po uzoru na onaj u Kombinatu. Navodno su po njegovom dolasku svi sekretari dobili dva tjedna da pripreme razvojne programe za svoje odjele, a nakon njegove evaluacije samo jedan je zadržao svoje radno mjesto (D. Režek u razgovoru s autorom, 30. lipnja 2016.).

Režekovom ulogom u poduzeću i lokalnoj zajednici najplastičnije se može ilustrirati prožetost čvrstih veza Kombinata i općinskog rukovodstva. Iz Zagreba se vratio 1961. kao svježe diplomirani inženjer, a kao što je već spomenuto, tadašnji općinski prvaci jedva su dočekali da ga zaposle kao izrazito potrebitog visokokvalificiranog radnika u građevinskom poduzeću i u školi (ibid.). Od samog početka Graditeljska škola bila je infrastrukturno poprilično skromna, pa ne iznenađuje da je trinaest godina kasnije kao predsjednik Skupštine općine među važnije projekte uvrstio izgradnju novog školskog centra usmjerenog na građevinske profesije (GŠC) (“Građevinski školski...”, GKM, 9. rujna 1977.). Moderna obrazovna tvornica stvarala je kvalificirane tesare, limare, zidare i ostala zanimanja iz domene 
građevine, ali isto tako bila je početna stepenica za buduće inženjere i druge građevinske stručnjake (ibid.). Također, škola je gravitirala puno šire od područja same općine te je učenike dobivala iz cijelog područja između Čakovca i Zagreba, zbog čega je bilo nužno sagraditi i đački dom (ibid.). GŠC je u konačnici rasteretio poduzeće u usputnom stvaranju polukvalificiranih radnika te je postao svojevrstan vanjski pogon za proizvodnju kadrova.

U zadnjem mjesecu 1976. GK je potpisao niz općinskih i republičkih samoupravnih sporazuma za upis zajma namijenjenih nizu infrastrukturnih i komunalnih projekata (“Osam samoupravnih...”, GKM, 3. veljače 1976.). Među njima su bili oni iz elektroprivrede i vodoprivrede potpisani s republičkom Vladom, koji su se djelomično ticali i hidroelektrana na Dravi. Naime, godine 1975. otvorena je $H E$ Varaždin kao dvadeseta u nizu "stepenica" ili centrala za proizvodnju električne energije na toj rijeci, uz one ranije sagrađene u Austriji i Sloveniji (Režek, 2003). $\mathrm{Na}$ dijelovima rijeke koja opasava južni dio Međimurja bila su planirana dva takva objekta, s nazivima Čakovec i Donja Dubrava. Međutim, za Režekova su mandata u općini, zbog preširoke disperzije odgovornosti političkog odlučivanja ostvarene novim Ustavom iz 1974., a u vrtlogu lokalnih političkih interesa, ti projekti zaustavljeni (ibid.). Zastoj je trajao sve do ranih 1980-ih, odnosno do trenutka kada je Režek već obnašao dužnost republičkog sekretara za građevinu u vladi Petra Flekovića (1978.-1984.). Čini se da je upravo napredak u političkoj karijeri Režeku omogućio da stvori dovoljno političkog kapitala da može vršiti veći pritisak na lokalne organe kako bi oni nastavili izgradnju energetskih tvornica na Dravi (ibid.). Po njegovom odlasku iz Vlade prestalo se graditi daljnje hidroelektrane na granici s Mađarskom iako su još sredinom dvadesetog stoljeća procijenjene kao objekti od strateške važnosti.

Potpunu afirmaciju ekonomske prevlasti Kombinata u političkom i društvenom životu općine Čakovec možemo prepoznati i u tome što je kao dobar poslovni domaćin novim industrijama sam gradio pogone. Tako je, na primjer, za Plivu 1977. podigao tvornicu Chicogo za proizvodnju kozmetičkih i higijenskih proizvoda ("Nova tvornica...", GKM, 16. ožujka 1977.). Godinu dana kasnije $G K$ se združio s Hidrotehnikom Čakovec te time sebi pripojio i posljednje građevinsko poduzeće u Međimurju (“GK Međimurje...”, GKM, 14. srpnja 1978.). Sada je Kombinat brojio preko šest tisuća radnika, a gigant je pored visokogradnje proširio specijalizaciju na niskogradnju i vodogradnju ("Prijedlog...", GKM, 16. ožujka 1978.). Nakon što je $G K$ u Čakovcu podigao manje-više sve najnužnije infrastrukturne, uslužne i obrazovne objekte, na red je došla i kultura, pa je u zadnjem mjesecu 1981. predsjednik Komiteta za prosvjetu, kulturu, fizičku i tehničku kulturu Sabora SR Hrvatske Stipe Šuvar dobio priliku otvoriti višenamjenski Dom kulture ("Dom kulture", GKM, 15. prosinca 1981.). 
Mirko Jagec još jednom je izabran za glavnog direktora u novom, pokazat će se zadnjem, mandatu, a upravo period od 1978. do njegovog odlaska 1981. bio je i najekspanzivniji za poduzeće ("Mirko Jagec...", GKM, 19. rujna 1978.). Odlazak kombinatskog prvog tehnokrata Režeka u Izvršno vijeće Sabora imalo je reperkusije na položaj Kombinata na tržištu (“Konstituiran Sabor...”, Delegatski vjesnik, 17. svibnja 1978.). GK je sada imao lobista na ključnom političkom mjestu u Zagrebu, što je poduzeću zasigurno pomoglo u dobivanju većih poslova. Tako na prijelazu decenije međimurski graditelji ugovaraju posao s najbogatijom jugoslavenskom proizvodnom kompanijom INA-om za izgradnju velikog Istraživačko-programskog centra u Šubićevoj (“S gradilišta...”, GKM, 3. srpnja 1981.). Također, osim bolje suradnje s poslovnim svijetom probijaju se kroz partijske redove i dobivaju posao izgradnje poznate političke škole SKJ Josip Broz Tito u Kumrovcu ("Politička škola...”, GKM, 9. listopada 1981.). Na prvi pogled čakovečki gigant nastavio je uporno bilježiti rast i u prvim godinama velike financijske krize uz koliko-toliko pozitivnu računovodstvenu bilancu. S ukupnim prihodom od 6,3 milijarde dinara $\mathrm{u}$ 1980. godini $G K$ se drugi put za redom našao u društvu 140 najvećih proizvodnih poduzeća Jugoslavije, i to na 98. mjestu liste koju je svake godine sastavljala beogradska Ekonomska politika (“140 najvećih...”, EP, 28. rujna 1981.).

No razdoblje kobne recesije koje je jugoslavensku ekonomiju bespovratno bacilo na koljena donijelo je poremećaje u procesu društvene reprodukcije. Nametnuta su mnogobrojna ograničenja, izraženi su veliki problemi gubitaka, a možda najveći problemi koji su gušili jugoslavensku ekonomiju bili su nelikvidnost i visoke obaveze prema bankama i međunarodnim vjerovnicima, teškoće u snabdijevanju reprodukcijskim materijalima, energentima i slično (Korošić, 1989: 55). Federalna vlast odgovorila je na spomenute probleme ograničavanjem investicija koje su u proteklom periodu bujale bez kontrole, a time je bio najviše pogođen upravo građevinski sektor. Uslijed takvih okolnosti $G K$ konačno konkretnije diversificira djelatnost i na računovodstveno-programske usluge svog Istraživačko-programskog centra (IPC), na čemu počinje zarađivati znatan novac. Međutim, ne uspijeva se prilagoditi novim uvjetima te uslijed krize i restrikcija za kapitalnu izgradnju počinje posrtati. Režek još jednom pokušava pomoći Kombinatu i nudi suradnju s INGRA-om, velikim i lukrativnim konzorcijem za građevinsku djelatnost izvan Jugoslavije, čiji je on postao direktor nakon ministarskog mandata. Međutim, iz nepoznatih razloga ozbiljnija suradnja nije se dogodila sve do pred kraj desetljeća i $G K$ nije uspio konkretnije izaći na inozemno tržište. U prvoj polovici 1990-ih proživio je tužnu tranzicijsku sudbinu i nestao, čime su se kao i u drugim slučajevima okoristili pojedinci legaliziranom pljačkom teško procjenjivog komada društvenog vlasništva. 


\section{Zaključak}

Iz perspektive teorije poslovne povijesti $G K$ postaje velikim poslovnim sustavom tek u svojem posljednjem uspješnom periodu između 1978. i 1981. godine. Tada se integrira s Hidrotehnikom, konačno diversificira svoju proizvodnju i u Međimurju monopolizira komercijalnu građevinsku djelatnost. Ujedno je taj period obilježio i zadnji mandat Mirka Jageca na mjestu glavnog direktora poduzeća, s čijim prvim izborom 1966. započinje tehnokratski eksperiment tog uspješnog poslovnog projekta. Osim Jageca, u stasanju poduzeća važnu je ulogu imao Danijel Režek, visokokvalificirani inženjer i tehnički direktor Kombinata, jer su njegov doprinos organizaciji $G K$ i modernizaciji proizvodnog procesa te kasnije zastupanje interesa Kombinata u političkim strukturama bitno utjecali na ukupni poslovni rezultat Kombinata. Tragovi razvojnog puta međimurskih građevinara ostali su duboko urezani u svakodnevicu današnjeg Čakovca, jer zdanja koja je kolektiv GK podigao u razdoblju od sredine 1960-ih do raspada poduzeća još uvijek dominiraju gradom.

Menadžment stručnjaka na čelu $G K$ promišljeno je investirao u svaku od komponenti koja je činila poduzeće, odnosno poštovao je najglasnije istican postulat privredne reforme: tehnološku modernizaciju postojećih industrijskih kapaciteta. Ciglana, pilana, šljunčara i pogoni za proizvodnju betona, a u prvom redu $G O$ kontinuirano su osvježavani suvremenom tehnologijom i sa Zapada i iz poznatih jugoslavenskih tvornica. Amortizacijske intervencije vršili su u skladu s potrebama tržišta za koje je Jagecov tim demonstrirao oštar senzibilitet. Primjer za to je povećanje kapaciteta proizvodnje opeke, koje se temeljilo na procjenama priljeva i potrošnje deviza radnika u inozemstvu. Tako su u Čakovcu i Međimurju osim važnog saveznika prepoznali i tržište kojim su iz godine u godinu sve više dominirali, a ta prisutnost materijalizirala se u hotelima, soliterima, bolnici, školama, plinofikaciji, kulturnom centru i drugim objektima. Fokusiranje na društveni standard, međutim, nije bilo izraz nekog prosvjetljenja uprave, već dio šireg ideološkog zaokreta u Jugoslaviji nakon Hrvatskog proljeća i smjene liberala u Srbiji i drugim republikama. Osim u Međimurju $G K$ se postepeno utvrđivao na tržištima preko Drave, najviše na turističkim projektima u Istri i poslovnim te stambenim objektima u Zagrebu.

No petnaestogodišnji period ubrzanog razvoja od 1966. do 1981. godine, kojim se bavi ovaj članak, ima i drugu stranu medalje. Procvat građevinskog sektora u Jugoslaviji treba promatrati u kontekstu ekonomije kojom su vladale nekontrolirane investicije zbog decentralizacije odlučivanja te nerješivog problema vanjskog zaduživanja i kronične nelikvidnosti. U tim uvjetima uprava se dobro snalazila prelijevajući financije iz fonda $u$ fond i živeći od novih projekata, ali neslužbeni bankrot Jugoslavije izazvan velikom naftnom krizom 1979. znatno je usporio razvoj Kom- 
binata. Također, u nadmetanju tržišnog i samoupravno-socijalističkog svjetonazora, u jugoslavenskom svijetu velikih poslovnih sustava prevladao je ovaj prvi. S jedne strane, činjenica je da je Kombinat kroz svoj rast gotovo potpuno sam sagradio moderne dijelove općine Čakovec. S druge strane, nakon provođenja privredne reforme od 1965. lov na dohodak odnosno profit i ekonomsku racionalizaciju sve više je postajao prioritet u odnosu na društvenu vrijednost, što se u poduzeću manifestiralo kroz tehnokratski princip upravljanja i vođenja poslovne politike.

Pod tim se podrazumijevaju mjere kao što su otpuštanje petine radne snage $u$ doba kada je Kombinat tek počinjao s radom te čuvanje niskih osobnih dohodaka s ciljem povećanja volumena poslovnog fonda i postizanja konkurentnosti na gusto naseljenom tržištu građevinskih poduzeća. Misli se i na zavođenje discipline na gradilištima kroz radne naloge i kadroviranje menadžmenta temeljeno na stručnosti bez isticanja dotad nezaobilaznih "društveno-moralnih" kvaliteta novih upravitelja. Isto tako, u trenutku kada je Kombinat narastao dovoljno da si može priuštiti artikuliranje političkih stavova koji se tiču šire društvene problematike općine, i tu je uprava pokazala manjak socijalne osjetljivosti. Naime, nisu pronašli mjesta za solidariziranje s prosvjetnim radnicama i radnicima u borbi za bolji ili samo dostojanstveni životni standard koji je neprestano trpio pod rastućim cijenama. Tek sredinom 1970-ih, s ideološkim zaokretom ulijevo i sustavnom implementacijom udruženog rada kroz "radničke amandmane" i Zakon o udruženom radu te jačom prisutnosti Saveza komunista, mijenjaju se i poslovne strategije u smjeru smanjivanja nezaposlenosti, većeg senzibiliteta prema radnim uvjetima i inzistiranja na životnom standardu radnika.

U konačnici, kao što je zaključio Ignac Bel već 1970. godine, "povijest Kombinata je povijest Čakovca i Međimurja". Od sredine 1960-ih GK i općina Čakovec istovremeno započinju svoj zakašnjeli, ali ubrzani modernistički procvat. Čakovec svakako najsadržajnije prolazi kroz tu transformaciju jer iz zanatskog naselja izrasta u manji, ali moderan grad. S druge strane, Kombinat u uvjetima intenzivnije provedbe tržišne reforme svojom vertikalnom i horizontalnom integracijom udara temelje velikom poslovnom sustavu. Te dvije strukture, općina i poduzeće, brzo su razvile simbiotski odnos u kojem je Međimurje zbrinjavalo poduzeće lokalnim tržištem i radnom snagom, a poduzeće je zauzvrat općinu postepeno uvodilo u doba modernizma te postajalo sve čvršći ekonomski oslonac cijelog Međimurja. 


\section{LITERATURA}

\section{Knjige i članci}

Berle, Adolf, Means, Gardiner. 1969. The Modern Corporation and Private Property. New York: Harcourt, Brace \& World.

Bilandžić, Dušan. 1999. Hrvatska moderna povijest. Zagreb: Golden Marketing.

Buković, Ivan. 1964. Integraciona kretanja u privredi Hrvatske. Zagreb: Narodne novine.

Cassis, Youssef. 1997. Big Business. The European Experience in the Twentieth Century. Oxford: Oxford University Press.

Chandler, Alfred D. 1963. Strategy and structure. Cambridge: MIT Press.

Chandler, Alfred D. 1999. The Visible Hand: The Managerial Revolution in American Business. Harvard: Harvard University Press.

Duda, Igor. 2005. U potrazi za blagostanjem: o povijesti dokolice i potrošačkog društva u Hrvatskoj 1950-ih i 1960-ih. Zagreb: Srednja Europa.

Duda, Igor. 2010. Pronađeno blagostanje: Svakodnevni život i potrošačka kultura u Hrvatskoj 1970-ih i 1980-ih. Zagreb: Srednja Europa.

Fikfak, Jure, Prinčič, Jože. 2008. Biti direktor v času socijalizma. Ljubljana: Založba ZRC.

Jović, Dejan. 2003. Jugoslavija, država koja je odumrla. Zagreb: Prometej.

Kalšan, Vladimir. 2006. Međimurska povijest. Zagreb: Ritonja.

Kidrič, Boris. 1949. Karakter robnonovčanih odnosa u FNRJ. Zagreb: Naprijed.

Korošić, Marijan. 1989. Jugoslavenska kriza. Zagreb: Naprijed.

Lampe, John R. 1996. Yugoslavia as History - Twice there was a country. Cambridge: Cambridge University Press.

Obadić, Ivan. 2017. In pursuit of Stability: Yugoslavia and Western European Economic Integration, 1948-1970. PhD dis. Firenca: European University Institute.

O'Sullivan, Mary. 2000. Contest for Corporate Control: Corporate Governance and Economic Performance in the United States and Germany. Oxford: Oxford University Press.

Radelić, Zdenko. 2006. Hrvatska u Jugoslaviji (1945. - 1991.) - Od zajedništva do razlaza. Zagreb: Školska knjiga.

Rajović, Radošin (ur.). 1970. Jugoslovenski savremenici: Ko je ko u Jugoslaviji. Beograd: Hronometar.

Režek, Danijel. 2003. Hidroelektrane na Dravi. Građevinar, (55) 11: 647-653.

Rusinow, Dennison. 1977. The Yugoslav Experiment, 1948-1974. London: Royal Institute of International Affairs. 
Sirotković, Jakov. 1989. Ekonomska politika Jugoslavije od 1945. do 1988. Zagreb: Radovi Zavoda za ekonomska istraživanja.

Supek, Rudi. 1974. Participacija, radnička kontrola i samoupravljanje. Zagreb: Naprijed.

Unkovski-Korica, Vladimir. 2016. The economic struggle for power in Tito's Yugoslavia: from World War II to non-alignment. London: I.B. Tauris.

Whitley, Richard (ur.). 1992. European business systems: Firms and markets in their national contexts. London: Sage Publications.

Whitley, Richard. 1999. Divergent Capitalisms: The social structuring and change of business systems. Oxford: Oxford University Press.

Whitten, David, Whitten, Bessie. 2006. The Birth of Big Business in the United States, 1860-1914: Commercial, Extractive, and Industrial Enterprise. Westport, Conn: Praeger.

Woodward, Susan. 1995. Socialist Unemployment - The Political Economy of Yugoslavia, 1945-1990. Princeton: Princeton University Press.

Županov, Josip. 1967. O problemima upravljanja i rukovođenja u radnoj organizaciji. Zagreb: Ekonomski institut - Naučno istraživački centar Ekonomskog fakulteta.

Županov, Josip. 1985. Samoupravljanje i društvena moć. Zagreb: Globus.

\section{Izvori}

Arhiv Jugoslavije, f. 507 - "Savez Komunista Jugoslavije”.

Deveti kongres. Beograd: Komunist, 1969.

HR-DAM-205. Državni arhiv za Međimurje - fond 205: GK "Međimurje” Čakovec.

“Osnovni zakon o poduzećima”. Službeni list SFRJ. 17-354/1965.

Ustav Socijalističke Federativne Republike Jugoslavije sa Ustavnim Amandmanima i Ustavnim Zakonima. Beograd: Službeni list, 1971.

Program Saveza komunista Jugoslavije. Beograd: Komunist, 1958.

\section{Novine}

Delegatski vjesnik - godište 1978.

Ekonomska politika - godišta 1971. i 1979.-1980.

GK Međimurje - godišta 1966.-1981.

Vjesnik INE - godište 1970.

\section{Intervjui}

Danijel Režek - intervju održan 30. lipnja 2016. 


\author{
Saša Vejzagić \\ MARKET AND THE CITY: \\ SYMBIOSIS BETWEEN AN ENTERPRISE \\ AND A MUNICIPALITY IN YUGOSLAVIA \\ - THE CASE OF CONSTRUCTION ENTERPRISE \\ GK MEĐIMURJE FROM ČAKOVEC (1963-1981)
}

\begin{abstract}
Summary
The article traces the expansion of a Čakovec-based construction enterprise Građevni kombinat Međimurje from its formation in the 1960s until it reached the peak of its business growth at the very end of the 1970s. On one hand, it is a compelling history of technocracy, entrepreneurship, and business development in a deregulated semi-planned economy. On the other, it is the story of the modernisation of Yugoslav agricultural periphery and the transformative experience of a provincial city on the fringes of Belgrade's or Zagreb's political interests. Among other things, the research underlines some of the most relevant characteristics related to the formation of large business systems in self-management. It scrutinises the relations and interactions between business and politics on a local level. Indirectly, the article questions the success of the market reform in Yugoslavia and seeks the boundary between the company and the Party.
\end{abstract}

Keywords: GK Međimurje, Čakovec, Yugoslavia, Business History, SelfManagement

Saša Vejzagić je doktorand pri European University Institute u Firenci i suradnik na projektu "Mikrosocijalizam" pri Centru za kulturološka i povijesna istraživanja socijalizma u Puli.

Kontakt: Saša Vejzagić, European University Institute, Via della Badia dei Roccettini 9, 50014 Fiesole FI, Italija. E-mail: sasa.vejzagic@eui.eu 